\title{
The Effect of Work Motivation and Work Environment on Performance With Satisfaction as Intervening Variables Education Personnel Rektorate Andalas University
}

\author{
Dafruddin \\ Master of Management Study Program \\ Institute of Economic Science, Finance, Banking and Development Padang
}

\begin{abstract}
Heryanto
Chair of the Management Master Program, School of Finance and Banking (STIE "KBP"), JL Khatib Sulaiman No. 61 Lolong Belanti, Padang Utara 25136, West Sumatra, Indonesia
\end{abstract}

\begin{abstract}
This study aims to obtain empirical evidence regarding the effect of work motivation and work environment on performance with satisfaction as an intervening variable of unand rectorate education staff. The population in this study were all unand rectorate education staff totaling 351 people. The technique used in sampling is to use the census method, wich is 187 people. The type of research used is descriptive quantitative.The analysis shows that work motivation has a positive and significant effect on satisfaction of the Unand Rectorate education staff, indicated by significance values $t$, which equals to 0.001 smaller than $\alpha=0.05(0.001<0.05)$ with a regression coefficient of 0.206 . The work environment has a positive and significant effect on employee satisfaction of Unand rectorate education staff, which is indicated by a significance value $t$ of 0,000 smaller than $\alpha=0.05(0,000<0,05)$ with a regression coefficient of 0,374 . Motivation work has a positive and significant effect on the performance of Unand rectorate education staff, indicated by a significance value of $t$ of 0,000 smaller than $\alpha=$ $0.05(0,000<0,05)$ with a regression coefficient of 0,319 . Work environment is positively and significantly influencial to the performance of the Unand rectorate's education staff, indicated by a significant value t of 0.023 smaller than $\alpha=0.05(0.023$ $<0.05$ ) with a regression coefficient of 0.166 . Job satisfaction has a positive and significant effect to the performance of the UNAND Rectorate education staff, indicated by the significance value of $t$ is 0,000 smaller than $\alpha=0,05(0,000<0,05)$ with the coefficient regression of 0.390 .
\end{abstract}

Keywords: Work motivation, work environment, job satisfaction, performance

\section{INTRODUCTION}

In the current conditions, companies tend to experience a decline in performance. This is often caused by management failure in managing employees. The success of a company is very much determined by reliable human resources, therefore it is necessary to examine what factors can improve the performance of the employee. Motivation is an important thing for employees. Motivated employees will feel happier, healthier, and want to come to work. The lack of employee motivation can have a serious impact on the level of performance of employees in the company. According to Robbins (2013), humans will be encouraged to meet the strongest needs. According to the time, circumstances and experiences involved in following a hierarchy. The first level is physiological needs. After these needs are satisfied then the next need will be the main need. The second need is security. The third need is social needs. The fourth need is the need for respect. After these needs are met, new needs emerge, namely the fifth requirement of self-actualization or self-realization or fulfillment of satisfaction or achievement. 
The work environment in a company needs to be considered because the work environment has a direct influence on employees. A conducive work environment can improve employee performance and conversely an inadequate work environment can reduce employee performance.

According to Sedarmayanti (2009) in broad outline the work environment is divided into 2 namely:

\section{Physical Work Environment}

Physical work environment is all physical conditions found around the workplace that can affect employees both directly and indirectly.

\section{Non-Physical Work Environment}

Non-physical work environment is all the conditions that occur related to work relations, both relationships with superiors, fellow colleagues, or relationships with subordinates.

Performance is often interpreted as achieving tasks, where employees in work must be in accordance with the work program of the organization to show the level of organizational performance in achieving the organization's vision, mission, and goals. According to Sedarmayanti (2009), performance is the result of work that can be achieved by a person or group of people in an organization, in accordance with their respective authorities and responsibilities, in order to achieve the objectives of the organization in question legally and not in accordance with morals or ethics. Satisfaction is important for employees. Employees who have work certainly have high morale, so that their work performance will be maximized as well. On the other hand, employees with a workload of labor are low, causing their work performance to be bad. According to Hasibuan (2009: 202) job satisfaction is an emotional attitude that is fun and loves his work. This attitude is reflected by work morale, discipline, and work performance. Job satisfaction is enjoyed in work, outside work, and a combination of in and outside work.

Andalas University has a vision to become a leading and dignified university, with one of its mission is to develop an organization to improve the quality of good governance so that it is able to anticipate and accommodate strategic environmental changes, and has the goal of preparing students to become community members who have academic abilities and / or professional and competitive who can apply, develop and / or enrich the repertoire of science, technology and / or art. With this vision, mission and goals to realize Andalas University, it must improve and maximize its performance by providing the best public services to all stakeholders. If the performance of the institution does not experience an increase or even decreases, it is impossible for the organization's vision, mission and goals to be realized. This really depends on the performance of human resources in providing public services. Based on the background above, the formulation of the problem in this study is as follows:

1. What is the effect of work motivation on the satisfaction of education staff at the Andalas University Rector?

2. What is the influence of the work environment on the satisfaction of education staff at the Andalas University Rector?

3. What is the effect of work motivation on the performance of education staff at the Andalas University Rector?

4. What is the influence of the work environment on the performance of education staff the Andalas University Rector?

5. What is the influence of satisfaction on the performance of education staff the Andalas University Rector? 
6. What is the effect of work motivation on the performance of education staff the Andalas University Rector with job satisfaction as an intervening variable?

7. What is the influence of the work environment on the performance of education staff the Andalas University Rector with job satisfaction as an intervening variable?

In order for researchers to have a clear direction, it is necessary to set research objectives. The objectives to be achieved in this study are:

1. Test the effect of motivation on the satisfaction of the Andalas University Rector's education staff

2. Test the influence of the work environment on the satisfaction of the Andalas University Rector's education staff

3. Test the effect of work motivation on the performance of the Andalas University Rector's Education Staff

4. Test the influence of the work environment on the performance of the Andalas University Rector's education staff

5. Test the influence of satisfaction on the performance of Andalas University Rector's education staff

6. Test the effect of work motivation on the performance of Andalas University Rector's education staff with job satisfaction as an intervening variable

7. Test the influence of the work environment on the performance of Andalas University Rector's education staff with job satisfaction as an intervening variable

\section{REVIEW LITERATURE}

\section{Work Motivation}

\section{Understanding of motivation}

Motivation comes from the Latin word movore which means encouragement, desire, cause, reason someone does something. According to Simamora (2006), that motivation is a psychological push that leads and guides an individual towards a goal. Motivation is divided into two factors including motivator or often referred to as intrinsic motivation and hygiene factors or often called extrinsic motivation.

a. Intrinsic motivation is a motivation that encourages a person to excel in the individual, better known as motivational factors.

b. Extrinsic motivation is motivation that comes from outside the self which also determines a person's behavior in a person's life known as the theory of hygiene factor.

\section{Purpose of Motivation}

Hasibuan (2009: 146) says the goals of motivation include the following: (1) Increasing employee morale and job satisfaction. (2) Increase employee productivity. (3) Maintaining employee stability. (4) improve employee discipline. (5) Effective procurement of employees. (6) Creating a good working relationship atmosphere. (7) Increasing employee loyalty, creativity and participation. (8) Increase the level of welfare of employees. (9) Enhancing the sense of responsibility of employees for their duties. (10) Improve the efficiency of the use of tools and raw materials.

\section{Motivation Theories}

In general, motivation theory is divided into two categories, namely: content / content theory and process theory. Content motivation theory focuses on the factors in the person who strengthen, direct, support and stop their behavior. This theory tries to answer questions related to satisfying needs and encourages someone to work. The thing that motivates a person 
in work is to fulfill material and non-material needs and satisfaction obtained from the results of his work (Hasibuan, 2011). Some of the theories included in this theory include:

\section{a. Content Motivation Theory.}

Abraham Maslow's Hierarchy of Needs Theory according to Robbins (2013), humans will be encouraged to meet the strongest needs, according to the time, circumstances and experiences involved in following a hierarchy. The first level is physiological needs. After these needs are satisfied then the next need will be the main need. The second need is security. The third need is social needs, community. After social needs are met, the fourth need is the need for respect. After these needs are met, new needs emerge, namely the fifth requirement of self-actualization or self-realization or fulfillment of satisfaction or achievement.

b. Process Motivation Theory.

The motivation theory of this process basically tries to explain the purpose that makes someone behave in a certain way. According to this theory motivation arises because of the need (needs), then there is hope (expectancy) for the possibility of getting a reward (reward) that can be used to meet those needs (Mangkunegara, 2012).

\section{The Effect of Work Motivation on Performance}

Motivation as a psychological process in a person will be influenced by internal and external factors. Internal factors that can influence the giving of motivation to someone include:

The desire to be able to live, the desire to be able to have, the desire to get appreciation, the desire to be in power and the desire to be in power while external factors that affect one's work motivation are: conditions of work environment, adequate compensation, status and responsibility.

\section{Motivation Indicator}

The indicators used in the motivation variable use the theory suggested by Robbins (2013), a theory about the Hierarchy of Needs Theory proposed by Abraham Maslow, namely: physiological needs, security, ownership, social, self-esteem and actualization.

\section{Work Environment}

Sedarmayanti (2009) says broadly the work environment is divided into 2 namely, physical work environment and non-physical work environment. Physical work environment is all physical conditions found around the workplace that can affect employees directly or indirectly, such as lighting, air temperature, space for movement, security, cleanliness, music and others. While the non physical work environment is all the conditions that occur related to work relations, both relationships with superiors, fellow co-workers, or relationships with subordinates.

\section{Performance}

\section{Understanding of Performance}

In estimology, performance comes from the word work performance, the meaning of the word performance is a noun where one of the meanings is a thing done something that has been done.

Performance which is a translation of performance means:

1. work performance, implementation of work, which is efficient.

2. A person's achievements / achievements regarding the assignment given to him. 
3. The results of the work of a worker, a management process or organization as a whole, where theresults of the work must be demonstrated in a concrete manner and can be measured (compared to predetermined standards).

4. Performance is defined as a record of the outcome that results from a particular activity, for a certaint period of time.

\section{Performance assessment}

Performance assessment is a model of assessment and measurement that compares past planning and strategic executions, operating activities, the level of participation of organizational members, the level of competition of the organization's employees. Performance appraisal means evaluating the current performance of employees and / or in the past relative to their standards of achievement (Dessler, 2006)

\section{Factors Affecting Performance}

Hasibuan (2011) says that the factors that influence employee performance are: 1) effectiveness and efficiency 2) authority and responsibility 3) Discipline 4) Initiative

\section{Performance assessment indicators}

According to Mangkunegara (2012), there are six criteria in working including: 1). quality of work 2). quantity 3). timeliness 4). effectiveness 5). independence 6). work commitments

\section{Job Satisfaction}

\section{Definition of Job Satisfaction}

Job satisfaction is a feeling of pleasure that results from the perception of fulfilling a job or the value of completing an important work Raymon (2011).

\section{Factors Affecting Job Satisfaction}

According to Robbin (2003) there are several factors that influence employee job satisfaction, namely: 1) work 2). wages 3). kopitasi 4). supervisor 5). co-workers.

\section{Job Satisfaction Theory}

According to Rivai (2009: 856) the theory of job satisfaction that is quite well known is:

1. discreppancy theory, 2). justice theory (equity theory) 3). theory of two factors (two factor theory).

\section{Effect of Job Satisfaction on Performance}

Robbin (2006) says that satisfied employees will be able to increase their productivity in doing work and fostering relationships with potential customer companies, especially in service organizations. Employees who have a higher level of satisfaction tend to be friendly, responsive to customer complaints and have a high level of loyalty to the company so that they can build maximum customer value that can ultimately realize the organization's goals.

\section{Performance Satisfaction Indicator}

Luthans (2006: 243) says there are five (5) indicators that are used to measure job satisfaction:

1. The work itself, in this case where work provides an interesting task opportunity to learn, and the opportunity to accept responsibility.

2. Salary is the amount of wages received and the rate at which this is biased considered appropriate compared to other people in the organization.

3. Promotion opportunity is an opportunity to advance in the organization

4. Supervision is the supervisor's ability to provide technical assistance and support behavior. 
5. The work colleague is the level at which colleagues are technically clever and supportive social.

\section{Hypothesis}

The hypothesis is a temporary answer to the research problem. Based on the main problems stated above, about the influence of work motivation and work environment on performance with satisfaction as intervening variables, the hypothesis of this study are as follows:

H1: Work motivation has a positive influence and is significant for satisfaction

H2: The work environment has a positive and significant influence on satisfaction

H3: Work motivation has a positive and significant effect on performance

H4: The work environment has a positive and significant effect on performance

H5: Satisfaction has a positive and significant effect on performance.

H6: Work motivation has a positive and significant effect on performance with job satisfaction as an intervening variable.

H7: The work environment has a positive and significant effect on performance with job satisfaction as an intervening variable.

\section{RESEARCH LOCATION}

In this research, the location of the study was the education staff of the Rectorate of Andalas University, Padang.

\section{Conceptual Framework of Research}

Based on problem formulation and literature review above, the conceptual framework in this study can be described as follows:

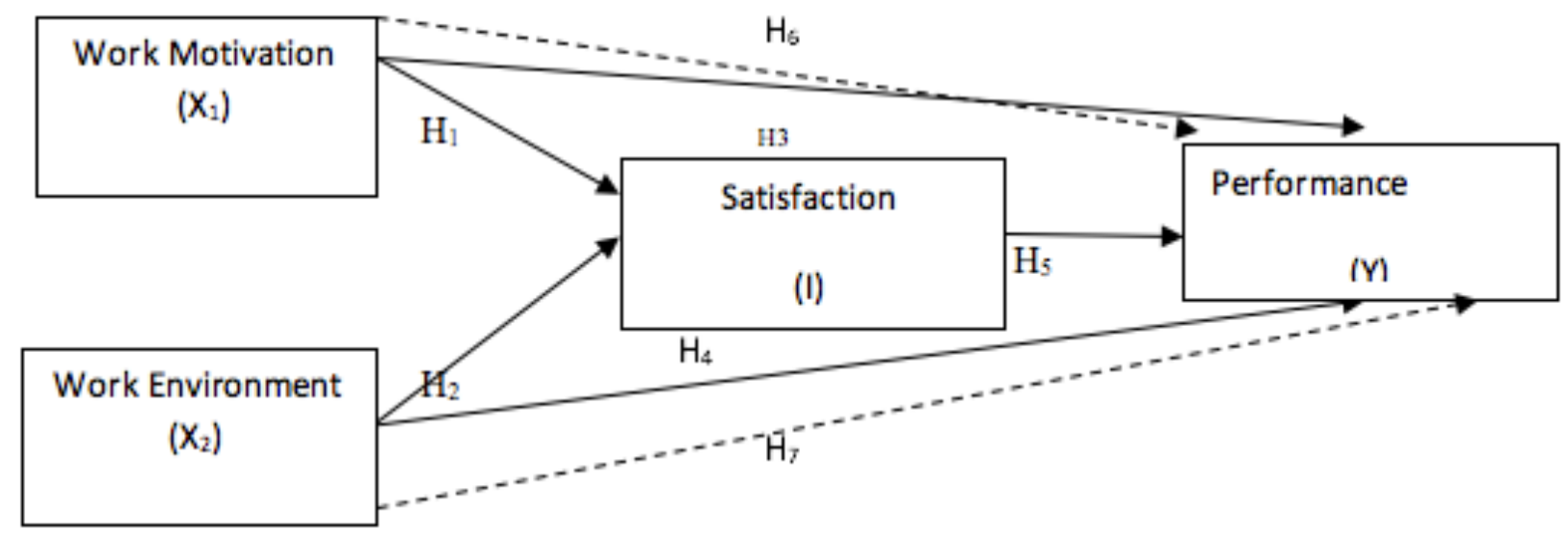

Figure 1: Conceptual framework

\section{RESEARCH METHODOLOGY}

The method used in this research is quantitative descriptive, with a multiple linear regression correlation analysis approach to measure the relationship between variables.

\section{Research Context}

The data collection technique in this research is survey technique, which is a technique used to determine individual perceptions and opinions of respondents about the topic to be studied, with research instruments in the form of interviews and questionnaires. The questionnaire was filled out directly by the respondents. The preparation of the questionnaire was carried 
out through several stages, namely by determining the indicator variable, arranging the points of the instrument and analyzing the study of the theory based on expert opinion.

\section{Measurement and Research Instruments}

The research instrument used was in the form of a questionnaire that was measured using a Likert scale. To measure variables from respondents in the form of work motivation, work environment, performance and job satisfaction. Then each answer from the respondent was given an alternative level, namely, Strongly Agree (SS), Agree (S), Disagree (KS), Disagree (TS) and Strongly Disagree (STS).

\section{Data Collection and Samples}

The population in this study were: all employees or educational staff of the Andalas University Rectorate, namely as many as 351 employees. In this study the sample used was as many as 187 employees. Sampling was done randomly using the Slovin formula according to Sugiyono (2011: 87) as follows:

Note:

$$
n=\frac{N}{1+N e^{2}}
$$

$\mathrm{N}=$ Number of population

e $\quad=$ Rate of reliability (5\%)

\section{Test Validity}

\section{ANALYSIS AND RESULTS}

According to Sugiyono (2012) usually the minimum requirement for an item is declared valid is if the correlation of each factor is positive and the amount is 0.3 and above.

\section{Test Validity of Work Motivation Variables}

Based on the validity test that has been done, obtained a description of the data regarding the validity test of work motivation variables, all declared valid because the value of the person correlation is greater than 0.30 as explained by Sugiyono (2012).

\section{Test the Validity of Work Environment Variables}

Based on the validity test that has been done, obtained a description of the data regarding the validity test of work environment variables, all of which are declared valid because the Pearson Correlation value is greater than 0.30 as explained by Sugiyono (2012).

\section{Test the Validity of Job Satisfaction Variables}

Based on the validity test that has been done, obtained a description of the data regarding the validity test of job satisfaction variables, all declared valid because the Pearson Correlation value is greater than 0.30 as explained by Sugiyono (2012). Where valid job satisfaction questionnaire items can be used as a reference for further analysis.

\section{Test the Validity of Performance Variables}

Based on the validity test that has been done, obtained a description of the data regarding the test of the validity of the performance variables, all of which are declared valid because the Pearson Correlation value is greater than 0.30 as explained by Sugiyono (2012).

\section{Reliability Test}

The reliability test in this study used the Cronbach Alpha formula with the help of SPSS (Statistical Package for Social Science). An instrument is said to be reliable if the Cronbach alpha value is greater than 0.6 as explained by Sekaran (2011). Based on the results of data 
processing that has been done, a summary of the results of the reliability shown in table 1 follows:

Table 1

Reliability Test Results

\begin{tabular}{|l|c|c|}
\hline \multicolumn{1}{|c|}{ Variable } & Cronbach's Alpha & Note \\
\hline Work Motivation $\left(\mathrm{X}_{1}\right)$ & 0,887 & Reliable \\
\hline Work Environment $\left(\mathrm{X}_{2}\right)$ & 0,807 & Reliable \\
\hline Work satisfaction $(\mathrm{I})$ & 0,899 & Reliable \\
\hline Performance $(\mathrm{Y})$ & 0,922 & Reliable \\
\hline
\end{tabular}

Source: primary data processed, 2018

Based on the results of the reliability test above for work motivation, work environment, job satisfaction and performance, it has a cronbach's alpha value greater than 0.6. So that it can be concluded that each of these variables has been supported by reliable statement items and can continue to be used in the further data processing stage.

\section{Analysis of Statistical Descriptions Variable Work Motivation}

Based on the total score of respondent's achievement (TCR), the figure is 0.834 or 83.4 percent. This shows that the TCR for the answers to work motivation variables is categorized as very strong. Based on the average rating of 187 respondents, it was seen that the respondents' perceptions of work motivation consisting of 20 question items had an average of 4.17. Based on these values,it can be concluded that the average respondent agrees (score 4) for each item of questions about motivation proposed by the researcher. So the results of questionnaire data obtained on work motivation variables are included in the criteria quite well. This indicates that the overall education staff of the Andalas University Rector have a fairly good perception of work motivation.

\section{Variable Work Environment}

Based on the total score of respondent's achievement (TCR), the figure is 0.836 or 83.6 percent. This shows that the TCR for the answer score for the work environment variable is very strong. Based on the average rating of 187 respondents, it was seen that the respondents' perception scores on the work environment consisting of 20 question items had an average of 4.18. Based on these values, it can be concluded that the average respondent agrees (score 4) for each item question about the work environment proposed by the researcher. So that the results of questionnaire data obtained in the work environment variable are included in the criteria quite well. This indicates that the overall education staff of the Andalas University Rectorate have a fairly good perception of the work environment as the results of the questionnaire about respondents' perceptions of work motivation.

\section{Variable Job Satisfaction}

Based on the total score of respondent's achievement (TCR), the figure is 0.828 or 82.8 percent. This shows that the TCR for the answer score of the job satisfaction variable is very strong. Based on the average rating of 187 respondents presented in table 4.9 above, it can be seen that the respondents' perceptions of job satisfaction consisting of 20 question items had an average of 4.14. Based on these values, it can be concluded that the average respondent agrees (score 4) for each item of questions about satisfaction proposed by the researcher. So that the results of questionnaire data obtained on the variable job satisfaction are included in the criteria quite well. This indicates the overall education staff of the Andalas University Rectorate has a fairly good perception of job satisfaction. 


\section{Performance variable}

Based on the total score of respondent's achievement (TCR), the figure is 0.832 or 83.2 percent. This shows the TCR for the answer score of the performance variable in the very strong category. Based on the average assessment of 187 respondents presented in table 4.10 above, it can be seen that the performance consisting of 20 question items has an average of 4.16. it can be concluded that the average value obtained in the performance variable is included in the criteria quite well. This indicates that overall the Andalas University Rectorate's education staff has a pretty good performance.

\section{Classical Assumption Test Model 1 Normality Test}

Data normality test aims to test whether in the dependent variable regression model and the independent variable both have a normal distribution or not (Ghozali, 2006). The test for normality test in this study used graph analysis, namely the normal P-P test plot and statistical analysis using the Kolmogorov-Smirnov One Sample test (K-S Test).

\section{Normal P-P Test Plot}

Normality testing with graph analysis is by looking at the spread of data on the diagonal axis on the normal graph P-P Plots of regression residual standardized, In this study the results show that the data are normally distributed because data spreads around the diagonal line and follows the direction of the diagonal line.

\section{Kolmogorov-Smirnov Normal Test (K-S Test).}

Data normality test can be done by Kolmogorov-Smirnov statistical test. The results of the One Sample Kolmogorov-Smirnov statistical test in this study obtained the Kolmogorov-Smirnov value of 1,179 with asymp. Sig of 0.124 , meaning that the value of 0.124 was greater than 0.05 $(0.124>0.05)$. Thus it can be explained that the data used for this study are normally distributed or meet normality test requirements.

\section{Test Autocorrelation}

Autocorrelation test aims to determine whether or not there is a correlation between data based on the time sequence. A good regression model is a regression that is free from autocorrelation. In this study, autocorrelation testing using a test method that is often used is the Durbin-Watson Test (DW test). For testing autocorrelation using the DW test, the following conditions:

a. If DW is smaller than -2 , it means that there is autocorrelation.

b. If DW is between -2 and +2 , then there is no autocorrelation.

c. If DW is greater than +2 , then there is a negative autocorrelation

In this study the value of Durbin-Watson (DW) is 1.192 which means that the value is between -2 to +2 , so it can be said that there is no autocracy or no correlation between data based on time sequence and the regression model for this study is acceptable.

\section{Multicollinearity Test}

According to Ghozali (2006) the multicollinearity test aims to test whether in the regression model there is a correlation between independent (independent) variables. A good correlation model should not have a correlation between variables. To detect multicollinearity by making a hypothesis:

a. Tolerance value $<0.10$ or VIF $>10$ : multicollinearity occurs

b. Tolerance value $>0.10$ or VIF $<10$ : multicollinearity does not occur 
In this study it was found that the work environment variable had a VIF value of 1.563 and Motivation of 1.563. Thus it can be said that the regression equation model does not have a multicollinearity problem and can be used in this study.

\section{Test of Heteroscedasticity}

Heteroscedasticity test is used to test whether in the regression model variables occur from residual inequalities, one observation to another observation. A good regression model is not heteroscedasticity. The heteroscedasticity test in this study was carried out by looking at the scatterplot graph between the predictive value of the independent variable, ZPRED and the residual SRESID.

In this study a scatterplot graph shows that data is spread over and below the number 0 (zero) on the $\mathrm{Y}$ axis and there is no clear pattern in the spread of the data. This means there is no heteroscedasticity in the regression equation model, so that a decent regression model is used to predict the effect of work motivation

\section{Classical Assumption Test Model 2 Normality Test}

Data normality test aims to test whether in the dependent variable regression model and the independent variable both have a normal distribution or not (Ghozali, 2006). The test for normality test in this study used graph analysis, namely the normal P-P test plot and statistical analysis using the Kolmogorov-Smirnov One Sample test (K-S Test).

\section{Normal P-P Test Plot}

Testing for normality with graph analysis is by looking at the spread of data on the diagonal axis in the normal P-P Plot of regression standardized residual graph, in this study. the results show that the data is normally distributed because the data spreads around the diagonal line and follows the direction of the diagonal line.

\section{Kolmogorov-Smirnov Normal Test (K-S Test).}

Data normality test can be done by Kolmogorov-Smirnov statistical test. The results of the One Sample Kolmogorov-Smirnov statistical test in this study obtained the Kolmogorov-Smirnov value of 0.751 with asymp. Sig of 0.625 meaning that the value of 0.625 was greater than 0.05 (0.625>0.05). Thus it can be explained that the data used for this study are normally distributed or meet normality test requirements.

\section{Autocorrelation Test}

Autocorrelation test aims to determine whether or not there is a correlation between data based on the time sequence. A good regression model is a regression that is free from autocorrelation. In this study, autocorrelation testing using a test method that is often used is the Durbin-Watson Test (DW test). For testing autocorrelation using the DW test, the following conditions:

a. If DW is smaller than -2 , it means that there is autocorrelation.

b. If DW is between -2 and +2 , then there is no autocorrelation.

c. If DW is greater than +2 , then there is a negative autocorrelation

In this study the value of Durbin-Watson (DW) is 1.012 which means that the value is between -2 to +2 , so it can be said that there is no autocracy or no correlation between data based on time sequence and the regression model for this study is acceptable . 


\section{Multicollinearity Test}

According to Ghozali (2006) the multicollinearity test aims to test whether in the regression model there is a correlation between independent (independent) variables. A good correlation model should not have a correlation between variables. To detect multicollinearity by making a hypothesis:

a. Tolerance value $<0.10$ or VIF $>10$ : multicollinearity occurs

b. Tolerance value $>0.10$ or VIF $<10$ : multicollinearity does not occur

In this study, it was seen that all motivation variables had a VIF value of 1.660 , a work environment with VIF 1.819 and job satisfaction with VIF 1.541. Thus it can be said that the regression equation model does not have a multicollinearity problem and can be used in this study.

\section{Heteroscedasticity Test}

Heteroscedasticity test is used to test whether in the regression model variables occur from residual inequalities, one observation to another observation. A good regression model is not heteroscedasticity. The heteroscedasticity test in this study was carried out by looking at the scatterplot graph between the predictive value of the independent variable, ZPRED and the residual SRESID.

In this study a scatterplot graph shows that data is spread over and below the number 0 (zero) on the $\mathrm{Y}$ axis and there is no clear pattern in the spread of the data. This means there is no heteroscedasticity in the regression equation model, so that a decent regression model is used to predict the effect of work motivation and work environment on performance with job satisfaction as an intervening variable.

\section{Results of Hypothesis Testing and Regression Analysis}

To test the hypothesis in this study, the coefficient of determination method was used, Simultaneous test (F test), multiple linear, path analysis, and test of significance of individual / partial parameters ( $\mathrm{T}$ test).

\section{Results of the Determination Coefficient Test}

Determination Coefficient (Error source not found.) Is used to find out how much the independent variable can explain the dependent variable. The value of determination is determined by the value of $\mathrm{R}$ square for simple regression and adjusted $\mathrm{R}$ square for multiple regression. Based on data processing using SPSS 16, the coefficient of determination of the two research models was obtained:

a. Model 1: $I=\alpha+\beta_{1} X_{1}+\beta_{2} X_{2}+\varepsilon$

b. Model 2: $Y=\alpha+\beta_{1} X_{1}+\beta_{2} X_{2}+\beta 2 I+\varepsilon$

In the first model, the $\mathrm{R}$ square value is 0.351 . This illustrates the work motivation variable $\left(\mathrm{X}_{1}\right)$ and work environment $\left(\mathrm{X}_{2}\right)$ explaining job satisfaction (I) of $35.1 \%$ while the rest is explained by other variables. In the second model the value of Adjusted R Square shows the number 0.499 . This means that performance can be explained by $49.9 \%$ by the two variables studied, namely the work environment and motivation with job satisfaction as an intervening variable, while the remaining $50.1 \%$ is explained by other variables that are not tested.

\section{Simultaneous Test Results}

Simultaneous tests (F test) are used to test whether all independent variables in the study can affect the dependent variable simultaneously or together in the research model. Testing is only 
done on the second model, because for the first model it is processed using simple regression which only has one independent variable that affects the dependent variable.

In this study obtained F-count value of 62.823 , with a sig value. $0,000<0,05$. With this it can be said that work motivation $\left(\mathrm{X}_{1}\right)$ and work environment $\left(\mathrm{X}_{2}\right)$ simultaneously have a significant effect on performance with job satisfaction (I) as an intervening variable.

\section{Results of Test for Significance and Regression Analysis Model 1}

Testing the first model in this study is using multiple regression. The variables tested on the first model are work motivation and work environment towards job satisfaction. The results of individual testing of work motivation and work environment on job satisfaction in the first model show:

1. The significant value of the work motivation variable is smaller than the significance rate which is $0.001<0.05$. Thus, $\mathrm{H}_{0}$ is rejected, $\mathrm{H}_{1}$ is accepted, meaning that the independent variables of work motivation have a positive and significant effect on job satisfaction

2. The significance value of the work environment variable is $0,000<0,05$. Thus, $\mathrm{H}_{0}$ is rejected, $\mathrm{H}_{2}$ is accepted, meaning that the independent variable of the work environment has a significant positive effect on job satisfaction.

Based on the first model equation can be formed, namely:

$$
I=34,365+0,206 X_{1}+0,374 X_{2}+\varepsilon
$$

The meaning of the equation produced is as follows:

1. The constant value obtained by 34,365 states that if the independent variable of work motivation $\left(\mathrm{X}_{1}\right)$, the work environment $\left(\mathrm{X}_{2}\right)$ is zero, then the variable job satisfaction will be positive at 34,365

2. The value of the regression coefficient of work motivation variable $\left(\mathrm{X}_{1}\right)$ of 0.206 means that work motivation has a positive relationship to job satisfaction (I). This shows that every increase in respondents' perceptual scores about 1 unit work motivation, assuming the other independent variables are constant, will increase the job satisfaction score by 0.206 .

3. The value of the regression coefficient of the work environment variable $\left(\mathrm{X}_{2}\right)$ of 0.374 means that the work environment has a positive relationship to job satisfaction (I). This shows that each increase in respondents' perceptual score 1 unit about the work environment, assuming the other independent variables are constant, will increase the job satisfaction score by 0.374 .

\section{Model II}

Testing the second model in this study is using multiple regression. The variables tested on the second model are work motivation, work environment, job satisfaction on performance. The following is the result of data processing for the second model.

The results of individual testing of work motivation and work environment on performance in the second model as follow:

1. The value of significant $t$ is smaller than the tariff of significance which is $0,000<0,05$. Thus, $\mathrm{H}_{0}$ is rejected, $\mathrm{H}_{3}$ is accepted, meaning that the independent variables of work motivation have a positive and significant effect on performance. 
2. The significance value of the work environment variable is $0.023<0.05$. Thus, $\mathrm{H}_{0}$ is rejected, $\mathrm{H}_{4}$ is accepted, meaning that the independent variables of the work environment have a significant positive effect on performance.

Based on the table above, the second model equation is obtained as follows:

$$
Y=23,719+0,399 X_{1}+0,312 X_{2}+\varepsilon
$$

The meaning of the equation produced is as follows:

a. The constant value obtained by 23.719 states that if the independent variable of work motivation $\left(\mathrm{X}_{1}\right)$, work environment $\left(\mathrm{X}_{2}\right)$ and job satisfaction (I) is zero, then the performance variable will be positive at 23.719 .

b. The value of the regression coefficient of work motivation variable $\left(\mathrm{X}_{1}\right)$ of 0.399 means that work motivation has a positive relationship to Performance (Y). This shows that every increase in respondents' perceptual scores about 1 unit work motivation, assuming other independent variables are constant, will increase the performance score by 0.399 units.

c. The value of the regression coefficient of the work environment variable $\left(\mathrm{X}_{1}\right)$ of 0.312 means that the work environment has a positive relationship to performance (Y). This shows that each increase in respondents' perceptual scores about a unit work environment, assuming the other independent variables are constant, will increase the performance score by 0.312 units.

The second model testing with the influence of intervening variables in this study is using multiple regression. The variables tested on the second model are work motivation, work environment, and job satisfaction as intervening with performance. The results of individual testing of work motivation and work environment and job satisfaction on performance in the second model show:

1. Value of significant value $t$ smaller than the tariff of significance that is $0,000<0,05$. Thus, $\mathrm{H}_{0}$ is rejected, $\mathrm{H}_{5}$ is accepted, meaning that the job satisfaction variable has a positive and significant effect on performance.

2. The value of significant $t$ is smaller than the significance rate of $0,000<0,05$. Thus, $\mathrm{H}_{0}$ is rejected, $\mathrm{H}_{6}$ is accepted, meaning that the independent variables of work motivation have a positive and significant effect on performance with the variable job satisfaction as an intervening variable.

3. The significance value of the work environment variable is $0.023<0.05$. Thus, $\mathrm{H}_{0}$ is rejected, $\mathrm{H}_{7}$ is accepted, meaning that the independent variable of the work environment has a significant positive effect on performance with the variable job satisfaction as an intervening variable.

Based on the table above, the second model equation is obtained as follows:

$$
Y=10,314+0,319 X 1+0,166 X 2++0,390 I+\varepsilon
$$

The meaning of the equation produced is as follows:

a. The value of the constant obtained 10.314 states that if the independent variable of work motivation $\left(\mathrm{X}_{1}\right)$, work environment $\left(\mathrm{X}_{2}\right)$ and job satisfaction (I) is zero, then the performance variable will be positive at 10.314 .

b. The value of the regression coefficient of work motivation variable $\left(\mathrm{X}_{1}\right)$ of 0.319 means that work motivation has a positive relationship to Performance (Y). This shows that every increase in respondents' perceptual scores about 1 unit work motivation, 
assuming other independent variables are constant, will increase the performance score by 0.319 units.

c. Regression coefficient value of work environment variable $\left(\mathrm{X}_{1}\right)$ of 0.166 means that the work environment has a positive relationship to performance (Y). This shows that each increase in respondents' perceptual scores about a unit work environment, assuming the other independent variables are constant, will increase the performance score by 0.166 units.

d. Value of regression coefficient variable job satisfaction (I) of 0.390 means job satisfaction (I) has a positive relationship to performance (Y). This shows that each increase in respondents' perceptual scores about 1 unit work satisfaction, assuming the other independent variables are constant, will increase the performance score by 0.390 units.

\section{Path Analysis}

The testing of this study also uses path analysis which is an extension of multiple linear regression analysis. The two equation models using multiple regression analysis are conducted to determine the strength of the relationship of the independent variable to the intervening variable and also the strength of the relationship of the independent variable to the dependent variable. The results of this path analysis are based on the results of the second regression output to get the beta coefficient and find a direct and indirect relationship.

\section{a. Direct effect}

Work motivation and performance variables have a direct effect on beta values of P3 $=0.399$, work environment and performance variables have a direct effect on beta values of P4 $=0.312$, and between job satisfaction and performance have a direct effect on beta values of 0.390 .

\section{b. Indirect effects of work motivation on performance}

To prove whether job satisfaction is an intervening variable between work motivation and performance, multiplication between beta P1 $=0.206$, (the effect of work motivation on job satisfaction) and beta P5 $=0.390$ (the effect of job satisfaction on performance). The results of the multiplication of 0.0803 are indirect effects of work motivation variable $\left(\mathrm{X}_{1}\right)$ on performance (Y) through job satisfaction (I). The total indirect effect added to the beta value from the direct effect of the motivation variable on performance of P3 $=0.399$ added with an indirect effect of 0.0803 worth 0.479 . Indirect influence on this study can be said to have a significant positive effect according to the hypothesis because the beta value of the path calculation between work motivation and job satisfaction and between job satisfaction and performance is 0.479 , greater than the direct effect of work motivation on performance P3 = 0.399 .

\section{c. Indirect effects of the work environment on performance}

To prove whether job satisfaction is an intervening variable between the work environment and performance, multiplication between beta P2 $=0.374$ (the influence of the work environment on job satisfaction) and beta P5 $=0.390$ (the effect of job satisfaction on performance). The results of the multiplication of 0.1459 are indirect effects of work environment variables $\left(\mathrm{X}_{2}\right)$ on performance $(\mathrm{Y})$ through job satisfaction (I). The total indirect effect added to the beta value of the direct effect of environmental variables on performance of $\mathrm{P} 4=0.312$ added to the indirect effect of 0.1459 is worth 0.458 . Indirect influence on this study can be said to have a significant positive effect according to the hypothesis because the beta value of the calculation of the path between work environment and job satisfaction and between job satisfaction and performance is 0.458 , greater than the direct influence between the work environment and performance namely $\mathrm{P} 4=0.312$ 


\section{DISCUSSION}

The effect of Work Motivation on Job Satisfaction of Education Staff of the Andalas University Rectorate

Analysis of regression coefficient value of work motivation variable $\left(\mathrm{X}_{1}\right)$ of 0.206 means that work motivation has a positive relationship to job satisfaction (I). This shows that every increase in respondents' perceptual scores about 1 unit work motivation, assuming the other independent variables are constant, will increase the job satisfaction score by 0.206 . Significant value $t$ smaller than the significance rate which is $0.001<0.05$. Thus, $\mathrm{H}_{0}$ is rejected, $\mathrm{H}_{1}$ is accepted, meaning that the independent variables of work motivation have a positive and significant effect on job satisfaction.

The effect of Work Environment on Job Satisfaction of Educational Staff of the Andalas University Rectorate

Analysis of regression coefficient value of work environment variable $\left(\mathrm{X}_{2}\right)$ of 0.374 means that the work environment has a positive relationship to job satisfaction (I). This shows that each increase in respondents' perceptual score 1 unit about the work environment, assuming the other independent variables are constant, will increase the job satisfaction score by 0.374 . The significance value of the work environment variable is $0,000<0,05$. Thus, $\mathrm{H}_{0}$ is rejected, $\mathrm{H}_{2}$ is accepted, meaning that the independent variable of the work environment has a significant positive effect on job satisfaction.

\section{The effect of Work Motivation on the Performance of Educational Staff of the Andalas University Rectorate}

Analysis of regression coefficient value of work motivation variable $\left(\mathrm{X}_{1}\right)$ of 0.399 means that work motivation has a positive relationship to performance $(\mathrm{Y})$. This shows that every increase in respondents' perceptual scores about 1 unit work motivation, assuming other independent variables are constant, will increase the performance score by 0.399 units. Significant value $t$ is smaller than the significance rate, which is $0,000<0,05$. Thus, $\mathrm{H}_{0}$ is rejected, $\mathrm{H}_{3}$ is accepted, meaning that the independent variables of work motivation have a positive and significant effect on performance.

\section{The effect of Work Environment on the Performance of Educational Staff of the Andalas University Rectorate}

Analysis of regression coefficient value of work environment variable $\left(\mathrm{X}_{1}\right)$ of 0.166 means that the work environment has a positive relationship to performance (Y). This shows that each increase in respondents' perceptual scores about a unit work environment, assuming the other independent variables are constant, will increase the performance score by 0.166 units. The significance value of the work environment variable is $0.023<0.05$. Thus, $\mathrm{H}_{0}$ is rejected, $\mathrm{H}_{4}$ is accepted, meaning that the independent variables of the work environment have a significant positive effect on performance.

\section{Influence of Job Satisfaction on the Performance of Education Staff of the Andalas University Rectorate}

Analysis of regression coefficient value of job satisfaction variable (I) of 0.390 means job satisfaction (I) has a positive relationship to performance (Y). This shows that each increase in respondents' perceptual scores about 1 unit work satisfaction, assuming the other independent variables are constant, will increase the performance score by 0.390 units. The significance value of the job satisfaction variable is $0,000<0,05$. Thus, $\mathrm{H}_{0}$ is rejected, $\mathrm{H}_{5}$ is accepted, meaning that the job satisfaction variable has a significant positive effect on performance. In the first model, the $\mathrm{R}$ square value is 0.351 . This illustrates the work motivation variable $\left(\mathrm{X}_{1}\right)$ and work environment $\left(\mathrm{X}_{2}\right)$ explaining job satisfaction (I) of $35.1 \%$ 
while the rest is explained by other variables. In the second model the value of Adjusted $\mathrm{R}$ Square shows the number 0.499 . This means that performance can be explained by $49.9 \%$ by the two variables studied, namely the work environment and motivation with job satisfaction as an intervening variable, while the remaining $50.1 \%$ is explained by other variables that are not tested. This shows that job satisfaction has a positive effect on performance. The better the level of job satisfaction of the Andalas University Rector's education staff especially about motivation and work environment, it will increase the performance of the Andalas University Rectorate's education staff. Therefore, it further strengthens the conclusion that job satisfaction is an intervening variable the influence of the work environment and work motivation on performance.

\section{The effect of Work Motivation on the Performance of Education Staff of the Andalas University Rector ate with Job Satisfaction As an Intervening Variable}

Significant value analysis $t$ is smaller than the significance rate of $0,000<0,05$. Thus, H0 is rejected, $\mathrm{H} 6$ is accepted, meaning that the independent variables of work motivation have a positive and significant effect on performance with the variable job satisfaction as an intervening variable. Regression coefficient value of work motivation variable $\left(\mathrm{X}_{1}\right)$ of 0.319 means that work motivation has a positive relationship to Performance $(\mathrm{Y})$ with job satisfaction (I) as an intervening variable. This shows that every increase in respondents' perceptual scores about 1 unit work motivation, assuming the other independent variables are constant and job satisfaction is an intervening variable, will increase the performance score by 0.319 units. To prove whether job satisfaction is an intervening variable between work motivation and performance, multiplication between beta P1 $=0.206$, (the effect of work motivation on job satisfaction) and beta P5 $=0.390$ (the effect of job satisfaction on performance). The results of the multiplication of 0.0803 are indirect effects of work motivation variable $\left(\mathrm{X}_{1}\right)$ on performance $(\mathrm{Y})$ through job satisfaction (I). The total indirect effect added to the beta value from the direct effect of the motivation variable on performance of P3 $=0.399$ added with an indirect effect of 0.0803 worth 0.479 . Indirect influence on this study can be said to have a significant positive effect according to the hypothesis because the beta value of the path calculation between work motivation and job satisfaction and between job satisfaction and performance is 0.479 , greater than the direct effect of work motivation on performance $\mathrm{P} 3=0.399$.

\section{The effect of Work Environment on the Performance of Education Staff of the Andalas University Rectorate with Job Satisfaction As an Intervening Variable.}

Analysis of significant values $t$ smaller than the significance rate of $0,000<0,05$. Thus, $\mathrm{H}_{0}$ is rejected, $\mathrm{H}_{7}$ is accepted, meaning that the independent variables of the work environment have a positive and significant effect on performance with the variable job satisfaction as an intervening variable. Regression coefficient value of work environment variable $\left(\mathrm{X}_{2}\right)$ of 0.166 means that the work environment has a positive relationship to Performance (Y) with job satisfaction (I) as an intervening variable. This shows that every increase in respondents' perceptual scores about 1 unit work environment, with the assumption that other independent variables are constant and job satisfaction is an intervening variable, will increase the performance score by 0.166 units. To prove whether job satisfaction is an intervening variable between the work environment and performance, multiplication between beta P2 $=0.374$ (the influence of the work environment on job satisfaction) and beta P5 $=0.390$ (the effect of job satisfaction on performance). The results of the multiplication of 0.1459 are indirect effects of work environment variables $\left(\mathrm{X}_{2}\right)$ on performance $(\mathrm{Y})$ through job satisfaction (I). The total indirect effect added to the beta value of the direct effect of environmental variables on performance of $\mathrm{P} 4=0.312$ added with indirect effects of 0.1459 is worth 0.458 . Indirect 
influence on this study can be said to have a significant positive effect according to the hypothesis because the beta value of the calculation of the path between work environment and job satisfaction and between job satisfaction and performance is 0.458 , greater than the direct influence between the work environment and performance namely P4 $=0.312$.

\section{Theoretical Contributions}

\section{DISCUSSION AND CONCLUSIONS}

The contribution of theory in this study is as follows:

1. Work motivation has a positive influence and significance to the satisfaction of the Andalas University Rectorate's education staff.

2. The work environment has a positive and significant influence on the satisfaction of the education staff of the Andalas University Rectorate.

3. Work motivation has a positive and significant effect on the performance of the education staff of the Andalas University Rectorate.

4. Work environment has a positive and significant effect on the performance of the personnel of the Andalas University Rectorate's staff

5. Satisfaction has a positive and significant effect on the performance of the personnel of the Andalas University rectorate.

6. Work motivation has a positive and significant indirect effect on the performance of Andalas University Rectorate's education staff with job satisfaction as an intervening variable.

7. Work environment has a positive and significant indirect effect on the performance of Andalas University Rectorate's education staff with job satisfaction as an intervening variable.

\section{Managerial Implementation}

Based on the results of the research and the conclusions obtained, some useful implications were found for the Andalas University Rector so that the performance of the education staff increased. Therefore, researchers made several forms of implications that could help the Andalas University Rectorate in increasing work motivation, work environment, job satisfaction and performance are as follows:

1. Improving the working environment of the Andalas University Rector, the Andalas University Rectorate focuses more on the physical environment such as color management, workspace arrangement, music, security in leaving valuables in work rooms, equipment or investments neatly arranged and arranged in place of work and fair treatment from the leadership. Because the indicators of this work environment affect job satisfaction which has implications for the performance of the education staff of the Andalas University

2. Increase the work motivation of Andalas University Rectorate's education staff, such as salaries, benefits and good recognition and appreciation from colleagues when successfully carrying out work. Because work motivation affects the satisfaction and performance of the education staff of the Andalas University Rectorate.

\section{Limitations of the Study}

The limitations of this study are as follows

1. Further research is expected to develop the research model. Because this study only analyzes the work environment, work motivation and performance with job satisfaction as an intervening variable. It is recommended for the next researcher to add other variables that can explain in depth about the performance of the education staff.

2. Narrowing the sample becomes more specific so that results will be obtained more accurate research 
Dafruddin., \& Heryanto. (2019). The Effect of Work Motivation and Work Environment on Performance With Satisfaction as Intervening Variables Education Personnel Rektorate Andalas University. Archives of Business Research, 7(2), 103-120.

\section{References}

Dessler, Gery. (2006). Human Resource management, The Strategic Role of human Resource management,10 th Edition, Prentice Hall

Ghozali, Imam. (2011). Aplikasi Analisis Multivariate Dengan Program SPSS. Semarang, BP Undip

Hasibuan, H. Malayu S.P. (2009). Manajemen Sumber Daya Manusia. Edisi Revisi. Jakarta: PT Bumi Aksara.

Hasibuan, H. Malayu S.P. (2011). Organisasi dan Motivasi. Jakarta: PT Bumi Aksara

Luthans. F,2006, Prilaku Organisasi, Edisi 10, Penerbit Andi, Yogyakarta

Mangkunegera, A. Anwar Prabu. (2012). Manajemen Sumber Daya Manusia Perusahaan. Bandung, Remaja Roesdakarya

Raymond A. Noe, Jhon R. Hollenhec, Barry Gerhart, Patrick M. Wright (2011). Fundamentals of Human Resource Management, Fourth Edition, Published by MC Graw-Hill

Rivai, vithezal \&Segala, E.J, 2009, Manajemen Sumber Daya Manusia Untuk Perusahaan, Jakarta : Rajagrafindo Persada

Robbins, Stephen P. (2003) Prilaku Organisasi,10th Edition. New Jersy: Prentice Hall

Robbins, Stephen P. (2013) Organizational Behavior, Fiftheen Edition. New Jersey: Pearson Prentice Hall Inc.2005

Robbins, Stepen P. (2006). Prilaku organisasi. Edisi ke 10. Jakarta : Indeks Kelompok gramedia

Sekaran, Uma. (2011). Research Methods for Business: Metode Penelitian Untuk Bisnis. Jakarta: Salemba Empat.

Sedarmayanti. (2009). Manajemen Sumberdaya Manusia. Reformasi Birokrasi dan Manajemen Pegawai Negeri Sipil. Bandung : Refika Aditama.

Simamora, Hendry. (2006), Manajemen Sumber Daya Manusia,STIE YKPN. Edisi Ketiga Yogyakarta

Sugiyono.(2011), Metoda Penelitian Kuantitatif dan Kualitatif dan R \& D. Alfabeta, Bandung.

Sugiyono. (2012). Metode Penelitian Administrasi. Bandung, Alfabeta. 